\title{
Optimizing Sowing Date for the Productivity of Durum Wheat (Triticum turgidum L. var. Durum) in Central Highland of Ethiopia
}

\author{
Bizuwork Tafes Desta*, Almaz Meseret Gezahegn, Sisay Eshetu, Abuhay Takele \\ Department of Agronomy and Crop Physiology, Ethiopian Inistitute Agricultural Reseach, Debre Zeit Agricultural Research Center, Debre \\ Zeit, Ethiopia
}

\section{Email address:}

b.tafes@gmail.com (B. T. Desta), almimeseret@gmail.com (A. M. Gezahegn), siscoeshetu23@gmail.com (S. Eshetu),

kidumet94@gmail.com (A. Takele)

${ }^{*}$ Corresponding author

\section{To cite this article:}

Bizuwork Tafes Desta, Almaz Meseret Gezahegn, Sisay Eshetu, Abuhay Takele. Optimizing Sowing Date for the Productivity of Durum Wheat (Triticum turgidum L. var. Durum) in Central Highland of Ethiopia. Agriculture, Forestry and Fisheries.

Vol. 9, No. 2, 2020, pp. 28-32. doi: 10.11648/j.aff.20200902.12

Received: February 1, 2020; Accepted: February 21, 2020; Published: May 18, 2020

\begin{abstract}
The field experiments were carried out at Debre Zeit Agricultural Research Center during the main cropping season between 2015 and 2017 to determine best sowing date for durum wheat productivity. The treatments were consisted of a factorial combination of four sowing date (late-June, mid-July, Late-July and mid-August) and two durum wheat varieties (Ude and Mangudo). The experiment was laid out in a randomized complete block design with three replication. Results showed that the main effect of sowing date had a significant effect on growth, yield and yield components of durum wheat. In contrast, main effect of variety and interaction effects of variety with sowing date had not a significant effect on growth, yield and yield components of durum wheat. The highest aboveground biomass yield $(8990.7 \mathrm{~kg} / \mathrm{ha})$ and grain yield $(3504.6 \mathrm{~kg} / \mathrm{ha})$ were obtained when durum wheat was sown in mid-July, but it was not significantly different yield from late-June. Based on 30 years rainfall data, the possibility of occurrence of dry spell is less during this period. Therefore, sowing of durum wheat from late-June to mid-July can be recommended for durum wheat production in the study area.
\end{abstract}

Keywords: Durum Wheat, Sowing Date, Yield, Varieties

\section{Introduction}

Durum wheat (Triticum turgidum L. var Durum) is the second most cultivated wheat species in the world, next to common wheat [1]. Ethiopia is considered a center of diversity for durum wheat (Triticum turgidum $\mathrm{L}$ var. durum). The crop has been under cultivation since ancient times. It covers $24 \%$ of the total cultivated lands used for durum wheat in Ethiopia. It is mainly grown on heavy black clay soils (Vertisols) of highlands with altitude range of 1800 to 2800 meter above sea lavel exclusively under rain fed conditions [2]. Durum wheat is the best wheat for pasta products due to its strong gluten, excellent amber color and superior cooking quality. It consumed traditionally in Ethiopia in the form of whole wheat, fermented and leavened local bread [3]. Although Ethiopia is the center of origin for durum wheat and the crop plays a significant role for the farmers and industries, the average yield which is $2.2 \mathrm{t} / \mathrm{ha}$ [4] is far below the yield potential of the crop. Lack of improved varieties, inadequate and erratic rainfall, poor agronomic practices, diseases and insect pests are among the principal limitations to wheat production in Ethiopia [5]

Sowing date is one of the most important agronomic factors which need great emphasis for maximum yield of crops. Durum wheat grain yield are dependent on the environment, genetic factors and the interaction between them [6]. Optimum sowing date positively affect grain yield of wheat and causing better adjustment to the physiology, phenology and environmental conditions [7, 8]. In addition, the appropriate sowing date also affects the water, temperature and solar radiation available for the crop. The highest values of some vegetative characters, yield attributes 
and grain yields as well as enhancement in biological and economical yield occurred when wheat planted earlier [9].

A Sowing date trials at Debre Zeit Agricultural research center showed that the highest grain yield $(2306 \mathrm{~kg} / \mathrm{ha})$, was obtained when improved durum cultivars planted on June 22 [10]. However, the optimum calendar date for sowing varied from year to year, presumably due to variation in rainfall. Moreover, each variety have their own specific requirements for sowing dates, seed rate and nutrients to determining crop growth and productivity [11]. To this end, it is worth to investigate appropriate sowing date for new released varieties to advance production and productivity of durum wheat. Therefore, the present study was designed with the objectives to determine appropriate sowing date that can increase productivity of durum wheat varieties.

\section{Materials and Methods}

\subsection{Description of Experimental Site}

The field experiments were conducted at DZARC (Debre Zeit Agricultural Research Center) during three consecutive (2015 to 2017) cropping seasons under rain fed condition. The site is located in East Shewa Zone of Oromia Regional State. It is found at $47 \mathrm{~km}$ away from South East of the capital city of Ethiopia, Addis Ababa. Its geographical location is $8^{\circ} 44^{\prime} \mathrm{N}$ latitude and $38^{\circ} 58^{\prime} \mathrm{E}$ longitude. The altitude is about 1900 meter above sea level. The soil type of the site is Vertsiol [12]. The total monthly rainfall of the experimental site during 2015 to 2017 is presented in Figure 1. The area received total rainfall of $433.2 \mathrm{~mm}, 459.6 \mathrm{~mm}$ and $596.3 \mathrm{~mm}$ during 2015, 2016 and 2017 cropping season (June to December) respectively.

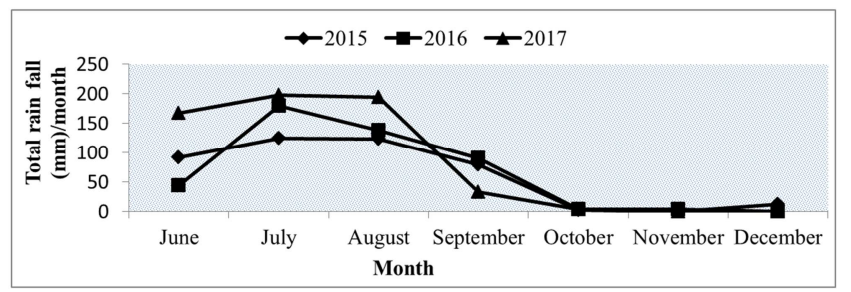

Figure 1. In 2015-2017 total monthly rainfall during the cropping season (June to December) at DZARC.

\subsection{Experimental Design and Treatments}

The experiment was laid out in a randomized complete block design with three replications. The treatments were consisted a factorial combination of four sowing date (lateJune, mid-July, Late-July and mid-August) and two durum wheat varieties (Ude and Mangudo). The plot size of $9 \mathrm{~m}^{2}$ $(3 \mathrm{~m} \times 3 \mathrm{~m})$ was used for all treatments. The spacing between blocks and plots was $1 \mathrm{~m}$ and $0.5 \mathrm{~m}$, respectively. Each plot consisted of fifteen rows and spaced $20 \mathrm{~cm}$ apart. The net central unit areas of each plot consisting of eight central rows of $2.80 \mathrm{~m}$ long were harvested and used for yield determination, whereas the others two outer rows were kept as border plants.

\subsection{Experimental Field Management}

The field was ploughed and harrowed to fine the plot using a tractor. The seeds was sown with hand drilling at the rate of $150\left(\mathrm{~kg} \mathrm{ha}^{-1}\right)$ in $20 \mathrm{~cm}$ rows spacing. Recommended rate of $76 \mathrm{~kg} / \mathrm{ha} \mathrm{N}$ and $46 \mathrm{~kg} / \mathrm{ha} \mathrm{P}_{2} \mathrm{O}_{5}$ were applied. Urea $(46 \% \mathrm{~N})$ and Diammonium phosphate (DAP) $\left(46 \% \mathrm{P}_{2} \mathrm{O}_{5}\right)$ were used as the source of $\mathrm{N}$ and $\mathrm{P}$ respectively. The full dose of $\mathrm{P}_{2} \mathrm{O}_{5}$ and one-third of $\mathrm{N}$ fertilizer were applied at the sowing time and remaining two-third of $\mathrm{N}$ fertilizer was applied at tillaring stage as a top dressing. Other agronomic practices were kept uniform for all treatments. The crop was harvested manually at physiological maturity, when the vegetative parts turned to yellow and samples were taken from a sample quadrat of $2 \mathrm{~m} \times 2 \mathrm{~m}$ for each plot.

\subsection{Data Collection}

Data such as, plant height, spike length, number of productive tillers, number of seed per spike, aboveground biomass yield $\mathrm{kg} / \mathrm{ha}$, grain yield $\mathrm{kg} / \mathrm{ha}$, thousand kernels weight and harvest index were taken. Thirty yeas rain fall data were taken form DZARC to confirmed the onset, endset and length of growing period in the study area.

\subsection{Data Analysis}

The data subjected to combined analysis of variance (ANOVA) over years after confirmation of homogeneity of error variance using Gen Stat version $17^{\text {th }}$ ed software program. The means were compared by LSD method at 0.05 probability level. The long year (1987-2017) historical rainy seasons and dry spells (within the rainy season) were analyzed based INSTAT soft ware years daily weather data.

\section{Results and Discussion}

\subsection{Plant Height}

The combined analysis of variance over years showed that the effect of sowing date was significantly $(\mathrm{P}<0.001)$ affected the plant height. However, main effect of variety and their interaction effect with sowing date were not significant. The tallest plant height $(77.19 \mathrm{~cm})$ was obtained from sown in mid-July but it was at par with plant height recorded from sown in late-June. The shortest plant height $(66.65 \mathrm{~cm})$ was recorded on delayed sowing (mid-August). In general, lateJune to mid-July sowing increased plant height of durum wheat. This increment in plant height might be due to the fact that at early sowing crop may have enjoyed better environmental conditions especially soil moisture, temperature and solar radiation which resulted to tallest plants. In conformity with this result, [13] reported that increasing of plant height of wheat in early sowing.

\subsection{Spike Length}

Combined analysis of variance over three years (2015 and 2017) revealed that only main effect of sowing dates had a significant effect $(\mathrm{P}<0.05)$ on spike length of the crop (Table 
1). In contrast, the main effect of variety and the interaction between variety and sowing dates did not affect spike length. Among different sowing dates, the longest spike length (7.06 $\mathrm{cm})$ recorded when the crop was sown in mid-July, whereas the shortest of spike length $(6.22 \mathrm{~cm})$ obtained when the crop sown in mid-August (Table 1). Generally, spike length was increased by about $13.83 \%$ when the crop was sown on midJuly as compared to that of delayed sowing (mid-August). These results are strongly supported by [14] who reported sowing date is significant influence on the spike length of wheat crop.

\subsection{Number of Productive Tillers/Plant}

Neither the main effect nor the interaction effect of variety and sowing date were significant on number of productive tillers per/plant (Table 1).

\subsection{Number of Seeds per Spike}

Number of seeds per spike was significant $(\mathrm{P}<0.05)$ effect was observed by main effect of variety and sowing date. However, the interaction effects of variety by sowing date were not significant (Table 1). Ude variety gave the higher (42.49) seeds per spike as compared to Mnagudo variety (39.42). Regarding on the sowing date, sowing of durum wheat on late-June gave the maximum number of seed per spikes (43.82) as compared to mid-August which showed the lowest (37.96) value for number of seeds per spike (Table 1). Similar observations are in line with those of [13].

Table 1. Means of spike length, plant height, number of productive tillers and number of seed per spike of durum wheat as influenced by variety and sowing date at Debre Zeit in 2015 to 2017 cropping season.

\begin{tabular}{|c|c|c|c|c|}
\hline \multicolumn{5}{|l|}{ Treatments } \\
\hline Variety & PH (cm) & SL (cm) & NPT & NSP \\
\hline Ude & 72.84 & 6.82 & 6.98 & $42.49 a$ \\
\hline Mangudo & 71.72 & 6.70 & 6.86 & $39.42 b$ \\
\hline $\operatorname{LSD}(0.05)$ & ns & ns & ns & 2.30 \\
\hline \multicolumn{5}{|l|}{ Sowing date } \\
\hline Late -June (28-June) & $76.73 a$ & $6.73 b$ & 7.13 & $43.82 \mathrm{a}$ \\
\hline Mid-July (15-July) & $77.19 \mathrm{a}$ & $7.06 \mathrm{a}$ & 7.05 & $43.00 \mathrm{a}$ \\
\hline Mid-August (15-August) & $66.65 b$ & $6.72 b$ & 6.60 & $37.96 b$ \\
\hline $\operatorname{LSD}(0.05)$ & 5.73 & 0.41 & ns & 3.26 \\
\hline CV $(\%)$ & 9.60 & 7.35 & 17.82 & 11.95 \\
\hline Variety X Sowing date & ns & ns & ns & ns \\
\hline
\end{tabular}

$\mathrm{PH}=$ plant height; $\mathrm{SL}=$ spike length; $\mathrm{NPT}=$ Number of productive tillers; NSP= number of seed per spike; Means with the same letter in columns are not significantly different at 5\% level of significance; $\mathrm{LSD}=$ least significant differences at $5 \%$; $\mathrm{CV}(\%)=$ Coefficient of variation

\subsection{Aboveground Biomass Yield}

Effect of variety and sowing date on aboveground biomass yield of durum wheat at Debre Zeit during 2015 and 2017 cropping season are presented in Table 2 . The combined analysis of variance over three years revealed significant $(p<0.05)$ difference among sowing dates for aboveground biomass yield. However, main effect variety and the interaction effects of the two factors (sowing date $\mathrm{x}$ variety) were not significant. The highest aboveground biomass yield (12806 kg/ha) was obtained when durum wheat was sown on mid-July, whereas lowest aboveground biomass yield $(10222 \mathrm{~kg} / \mathrm{ha})$ in case of late sowing i.e. mid-August (Table 2). The total aboveground dry biomass yields obtained durum wheat was sown mid-July at Debre Zeit exceeded the lowest aboveground dry biomass yield produced by $25.28 \%$ compared to delay sown (mid-August). This yield advantage achieved in early sowing was mainly due to better stand establishment per meter of the crop, added more number of productive tillers/plant, longer spike length and plant height, cumulatively increased biomass yield. Previous research work indicated that at Debre Zeit Agricultural Research station, the highest aboveground biomass yield $(12306 \mathrm{~kg} / \mathrm{ha})$ for improved durum cultivars was obtained with early sowing (June 22) [10].

\subsection{Grain Yield}

Sowing date is one of the major factors that influence growth and yield of crops. The combined analysis of variance over three years revealed that significant $(p<0.05)$ difference among sowing dates for mean grain yield of durum wheat. However, the main effect of variety and the interaction effect of the two factors did not influence the grain yield (Table 2). The maximum grain yield $(3504.6 \mathrm{~kg} / \mathrm{ha})$ was produced when the crop was sown in mid-July compared to sown in mid-August which produced minimum grain yield (2500.9 $\mathrm{kg} / \mathrm{ha}$ ). However, the mean grain yield of durum wheat produced when the crop was sown in mid-July, statistically at par with the grain yield obtained from late-June) (Table 2). In general, sowing on mid-July at Debre Zeit, of durum wheat gave $40.13 \%$ enhancements in grain yield compared to delay sowing (mid-August). This might be due to the fact that sowing earlier, produced maximum vegetative and reproductive components like more number of plants emerged $/ \mathrm{m}^{2}$, more number of productive tillers/plant with better survival, more number of kernels/spike, which in return yielded more grain yield. Similarly to this result, the highest yield (2306 kg/ha) for improved durum cultivars was obtained with early sowing (June 22); with late August sowing, an $83 \%$ yield loss was incurred at Deber Zeit station [10]. In contrast with the current result, earlier research result showed that late sowing dates (early-August sowing produced $30 \%$ higher grain yields than that of early sowing dates (sowing in late-June through July) on vertisol [15]. 


\subsection{Thousand Kernels Weight and Harvest Index}

The combined analysis of variance indicated nonsignificant effects of variety and sowing dates as well as the interaction of these two factors on the thousand kernels weight and harvest index of durum wheat (Table 2). Thousand kernels weight is more governed by genetics rather than the environments. Although, statistically not significant but numerically the heavier seeds $(50.38 \mathrm{~g})$ and highest present of harvest index observed, when the crop was sown at early sowing. There was a gradual decrease in grain weight and harvest index with each successive sowing and the minimum grain weight $(48.13 \mathrm{~g})$ and harvest index (24.46) was observed in delay sown (mid-August).

Table 2. Means of aboveground biomass yield, grain yield and thousand kernels weight and harvest index of durum wheat as influenced by variety and sowing date at Debre Zeit in 2015- 2017 cropping season.

\begin{tabular}{|c|c|c|c|c|}
\hline \multicolumn{5}{|l|}{ Treatments } \\
\hline Variety & AGBY (kg/ha) & GY (kg/ha) & TKW (g) & HI (\%) \\
\hline Ude & 11560 & 3173.1 & 50.02 & 27.45 \\
\hline Mangudo & 11472 & 2906.5 & 48.71 & 25.33 \\
\hline $\operatorname{LSD}(0.05)$ & ns & $\mathrm{ns}$ & $\mathrm{ns}$ & $\mathrm{ns}$ \\
\hline \multicolumn{5}{|l|}{ Sowing date } \\
\hline Late -June (28-June) & $12556 \mathrm{a}$ & $3347.2 \mathrm{ab}$ & 50.38 & 27.35 \\
\hline Mid-July (15-July) & $12806 a$ & $3504.6 \mathrm{a}$ & 49.83 & 27.37 \\
\hline Late-July (30-July) & $10481 \mathrm{~b}$ & $2806.5 \mathrm{bc}$ & 49.13 & 26.77 \\
\hline Mid-August (15-August) & $10222 b$ & $2500.9 \mathrm{c}$ & 48.13 & 24.46 \\
\hline $\operatorname{LSD}(0.05)$ & 1470.9 & 689.21 & $\mathrm{~ns}$ & $\mathrm{~ns}$ \\
\hline $\mathrm{CV}(\%)$ & 15.32 & 17.19 & 17.49 & 15.45 \\
\hline Variety $\mathrm{x}$ Sowing date & $\mathrm{ns}$ & ns & ns & ns \\
\hline
\end{tabular}

$\mathrm{AGBY}=$ aboveground biomass yield; GY= grain yield; TKW=thousands kernel weight; HI= harvest index; Means with the same letter in columns are not significantly different at $5 \%$ level of significance; $\mathrm{LSD}=$ least significant differences at $5 \%$; CV $(\%)=$ Coefficient of variation

\subsection{Percentile Description of Onset, End Date, Length of Growing Duration of the Season}

The occurrence of rainy seasons and dry spells (within the rainy season) was carried out based on frequency analysis of 30 years (1987-2017) at DZARC daily weather data. The onset, end date and length of growing period are presented in
Table 3. Onset of rainy seasons occurred before $1^{\text {st }}$ dekad of June (2-Jun) was $25 \%$ while it occurred before $3^{\text {rd }}$ dekad of June (24-Jun) in $75 \%$ with coefficient of variation (CV) of $7.96 \%$ at DZARC. On the other hand, the end date of rainy season occurred before $3^{\text {rd }}$ dekad of September (26-Sep.) was $25 \%$ and occurred.

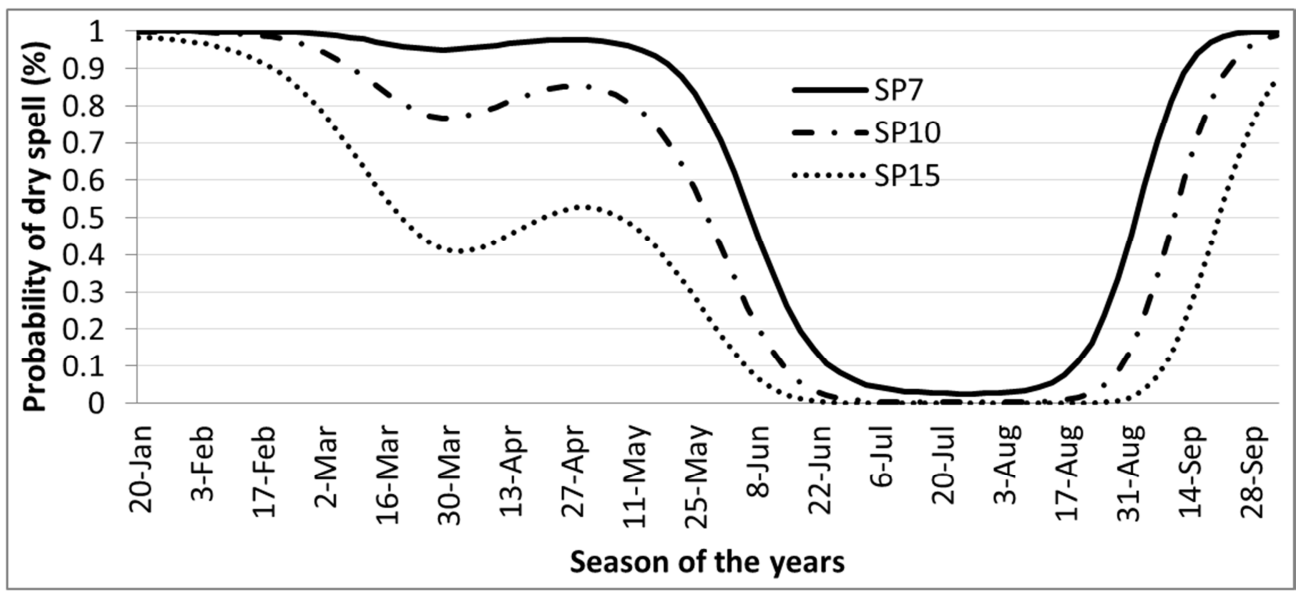

Source; (DZARC meteorology data)

Figure 2. Probability of dry spell period over 30 (1987-2017) at DZARC.

Table 3. Summary of Onset, end rain season and LGP for 30 years (1987 to 2017) at DZARC.

\begin{tabular}{lllll}
\hline & Statistical parameter & Onset & End date & LGP (No of days) \\
\hline & Minimum & 01-Jun & $16-$ Sep & 26-Sep \\
& Quartile 1 $(25 \%)$ & 02-Jun & $06-$ Oct & 100 \\
Debre Zeit & Median Quartile 2 $(50 \%)$ & 18-Jun & $07-O c t$ & 108 \\
& Quartile 3 $(75 \%)$ & 24-Jun & $23-O c t$ & 109 \\
& Maximum & 19-Jul & 03-Oct & 131 \\
& Mean & 16-Jun & 8.65 & 14.39 \\
\hline
\end{tabular}




\subsection{Probability of Dry Spell Occurrence}

As shown in figure 2, the probability of dry spell period of 7,10 and 15 days of dry spell $<10 \%$ occurrence are between 8-June to 10-August. The dry spell length occurred at seedling growth, flowering and grain filling stages more than $10 \%$ in the rain season of any of crop is most sensitive and potentially damaging [16]. The current result, also indicated that sowing of durum wheat between late June (28) to midJuly (15) less dry spell probability occurrence.

\section{Conclusion}

Based on the result, growth, yield components and yield of durum wheat were affected by the dates of sowing. Durum wheat sown in between late-June (28-June) to mid-July (15July) had a significant yield difference compared to late sowing dates (28-July and 15-August). The thirty year rainfall data showed $75 \%$ of a relative frequency of the onset of rain was on June 24 and an offset on October 07 . Moreover, less dry spell probability occurrence $<10 \%$ was shown in between, 22-June to 8-August. Therefore, we conclude that sowing of late-June to mid-July can be recommended for the durum wheat productivity at Debre Zeit.

\section{References}

[1] Pena RJ, Trethowan R, Pfeiffer WH and Ginkel M. (2002). Quality End-use. Improvement in Wheat: Compositional, Genetic, and Environmental Factors. In: Basra AS and LS Randhawa (Eds). Quality Improvement in Field Crops, Food Products Press, Binghampton, NY, 1-39.

[2] Tesemma, T. and Belay, G. (1991). Aspects of Ethiopian tetraploid wheats with emphasis on durum wheat genetics and breeding research. In: Gebre-Mariam, H., Tanner, D. G. and Hulluka, M., Eds., Wheat Research in Ethiopia: A Historical Perspective, IAR/CIMMYT, Addis Ababa. 47-71.

[3] Woyema, A., Bultosa, G., \& Taa, A. (2012). Effect of different nitrogen fertilizer rates on yield and yield related traits for seven durum wheat (Triticum turgidum L. var Durum) cultivars grown at Sinana, South Eastern Ethiopia. African Journal of Food, Agriculture, Nutrition and Development. 12 (3), 6079-6094.

[4] CSA (Central Statistical Agency) (2017). Agricultural Sample Survey 2016/2017 Agricultural Sample Survey. Agricultural sample survey, report on area and production of major crops, Addis Ababa, Ethiopia.
[5] Gorfu, D and Hiskias Y. (2000). Yield loss of crops due to diseases in Ethiopia. Ethiopian Journal Pest Manage. 5: 55-67.

[6] Coventry, D. R., R. K. Gupta, R. S. Poswal, R. S. Chhokar, R. K. Sharma, V. K. Yadav, S. C. Gill, A. Mehta, S. G. L. Kleemann, A. Bonamano, J. A. Cummins (2011). Wheat quality and productivity as affected by varieties and sowing time in Haryana, India. Field Crops Research, 123 (3): 214225.

[7] Silva, R. R., G. Benin, J. L. Almeida, I. C. B. Fonseca and C. Zucareli (2011). Grain yield and baking quality of wheat under different sowing dates. Acta Scientiarum Agron., 36 (2): 201-210.

[8] Ribeiro, T. L. P., G. R. Cunha, J. L. F. Pires, A. Pasinato (2009). Phenological responses of Brazilian wheat cultivars to vernalization and photoperiod. Pesquisa Agropecuária Brasileira, 44 (11): 1383-1390.

[9] Qasim M., Qamer M and Alam M. (2008). Sowing Dates Effect on Yield and Yield Components of Different Wheat Varieties. Journal Agricultural Research; 46 (2): 135-140.

[10] DZARC (Debre Zeit Agricultural Research Center) (1983). Durum Wheat Annual Reports 1977-83. Debre Zeit, Ethiopia.

[11] Dabre, WM, Lall, SB and Lngole, GL. (1993). Effects of sowing dates on yield, ear number, stomatal frequency and stomatal index in wheat. Journal Maharashatra Agricultural. University. 18: 64-66.

[12] WRB (World Reference Base) (2006). A framework for international classification, correlation and communication, world soil resource report 103, Rome, p68.

[13] Tahir M., Asghar Ali, Muhammad Ather Nadeem, Hussa A and Khalid F. (2009). Effect of Different Sowing Dates on Growth and Yield of Wheat (Triticum aestivum L.) Varieties in District Jhang, Pakistan. Pakistian Journal of life and social science. 7 (1): 66-69.

[14] Ahmed Z, Kalwar, Tunio, MA, Shaikh Y, Khan I, Jogi Q. (2018). Impact of Sowing Dates on the Growth and Yield of Wheat Variety Pakistan International Journal of Agronomy and Agricultural Research (IJAAR). 12 (5): 65-71.

[15] Tanner, D. G., Gorfu A. and Zewdie, K. (1991). Wheat Agronomy Research in Ethiopia: In: Wheat Research in Ethiopia: A historical Perspective, Addis Ababa, IAR/CIMMYT. Pp: 95-135.

[16] Girma Mamo (2005). Using seasonal climate outlook to advice on sorghum production in the Central Rift Valley of Ethiopia. PhD, Thesis. Faculty of Natural and Agricultural Sciences, Department of Soil, Crop and Climate Sciences, University of the Free State, Bloemfontein, South Africa. p189. 